\title{
Therapeutic efficacy of Cinnamomum tamala (Buch.-Ham.) and Aegle marmelos (L.) leaf
}

\author{
Sukumar Dandapat*, Manoj Kumar and M. P. Sinha \\ *Department of Zoology, Ranchi University, Ranchi, Jharkhand, India - 834008 \\ *email: eaddress.sukumar27@gmail.com
}

\begin{abstract}
Medicinal plants are widely used for therapy of various diseases and disorders due to presence of various bioactive phytochemicals. Among the studied phytochemicals polyphenol content was higher $(16.7 \pm 0.7 \mathrm{~g} / 100 \mathrm{~g}$ in $C$. tamala and $6.7 \pm 0.61$ $\mathrm{g} / 100 \mathrm{~g}$ in $A$. marmelos $)$ and flavonoids content was lower in both plants $(1.0 \pm 1.01 \mathrm{~g} / 100 \mathrm{~g}$ and $0.9 \pm 0.25 \mathrm{~g} / 100 \mathrm{~g}$ in $C$. tamala and A. marmelos respectively). Leaf extract of both plant were effective against $S$. aureus and $P$. mirabilis $(6-10 \mathrm{~mm} \mathrm{ZOI}$ and $100 \%$ inhibition at $0.25 \mathrm{mg}-5 \mathrm{mg}$ of leaf extracts in agar disk diffusion and broth dilution method respectively) and the leaf extract of both plant possess high antioxidant activity, $0.9 \%$ and $0.2 \%$ at $5 \mu \mathrm{g} / \mathrm{mL}$ concentration $4 \%$ and $7 \%$ at $100 \mu \mathrm{g} / \mathrm{mL}$ concentration of A. marmelos and C. tamala leaf extracts respectively. Aqueous leaf extract of both the plants did not show cytotoxicity by haemolysis at $0.2 \mathrm{mg} / \mathrm{mL}-1 \mathrm{mg} / \mathrm{mL}$ concentration.
\end{abstract}

Key -words: Phytochemical, disease, pathogenic, antioxidant, haemolytic.

\section{Introduction}

Infectious diseases are caused by pathogenic microorganisms such as Staphylococcus aureus and Proteus mirabilis are and are transmitted from one host to another via vectors [1]. S. aureus causes infection of wounds; urinary tract and $P$. mirabilis cause urethitis, cystitis, pyelonephritis, prostatitis and pneumonia [2].

Free radicals ROS and NOS (Reactive oxygen species and Reactive Nitrogen Species) are constantly formed in the human body but their excessive production during diseases and tissue injuries causes oxidative stress by hampering nucleic acids, lipids, and proteins, which ultimately leads to cellular cell death [3] which in turns in leads to various disorders like, Parkinson's disease, Allergic encephalomyelitis, Occular hemorrhage, Atherosclerosis, Keshan disease, Autoimmune nephrotic syndromes, endotoxin liver injury, diabetogenic actions of alloxan, aging and cancer $[4,5]$.

Medicinal plants contain wide variety of secondary metabolites such as tannins, terpenoids, alkaloids and flavonoids, which are associated with antioxidant and other medicinal properties against various disease and disorders [6] but plant saponins are associated with haemolysis and saponins are also used as adjuvant in vaccination [7].

Aegle marmelos commonly known as bael, belonging to the family rutaceae and Cinnamomum tamala belonging to family lauraceae have been tested against the pathogenic bacteria and .These plants are frequently used as natural antioxidant and medicine for treatment of various diseases and disorders such as wounds, urinary tract infection, urethitis, cystitis, pyelonephritis, prostatitis and pneumonia [8-10].

The present study is an attempt to evaluate the phytochemical screening, antipathogenic efficacy against $S$. aureus and $P$. mirabilis, total antioxidant capacity and cytoxicity of leaf extract of C. tamala and A. marmelos.

\section{Materials and methods \\ Collection of Plant material:}

The fresh and tender leaves were collected, dried in a shade under room temperature for six to seven days and then crushed into coarse powdery substance by 
using electric grinder. The coarse powdery substance was dried again and was then sieved to get fine powder using the fine plastic sieve, which was then stored in an air tight bottle in the laboratory until required [11].

\section{Extract preparation:}

$50 \mathrm{~g}$ of the sieved powder was weighed accurately and subjected to extraction in a soxhlet apparatus at room temperature using $\sim 350 \mathrm{~mL}$ methanol and distilled water separately. The extract obtained was filtered, concentrated after dryness in rotary flash evaporator maintained at $45^{\circ} \mathrm{c}$, percentage yield of each extract was calculated and the dried extract was stored in air tight containers at room temperature for further studies [11].

\section{Phytochemical screening:}

Total phenol was determined by FolinCiocalteau reagent, following Ramamoorthy and Bono [12]. Tannins were quantified as stated in the Quality control methods for medicinal plant materials [7]. Aluminium chloride colorimetric method was used with some modifications to determine flavonoids content [13]. Alkaloid was determined by the method used by Helrich [14]. Saponin content was determined following Obdona and Ochuko [15]. The details have been described elsewhere Kumar et al. [16, 17].

\section{Anti-bacterial analysis:}

Antibacterial efficacy of methanolic leaf extract of $C$. tamala and A. marmelos was carried out against Proteus mirabilis (MTCC 1249) and Staphylococcus aureus (MTCC 3160). In agar disk diffusion method comparing with standard antibiotic Gentamycin following Threlfall et al. [18] and by broth dilution method as proposed by Walker [19]. The details have been described elsewhere Kumae et al. [20].

\section{Anioxidant assay:}

Total antioxidant capacity of aqueous extract was determined spectrophotometrically and expressed as equivalent to ascorbic acid. Butylated hydroxy anisole (BHA) was used as reference standard [21]. The details have been described elsewhere Kumar et al. [22].

\section{Cytoxicity:}

Hemolytic activity of the aqueous leaf extract was determined using goat blood. An erythrocyte suspension was prepared by adding 5\% (by volume) of sodium citrate $(36.5 \mathrm{~g} / \mathrm{L})$ to fresh blood and centrifuged at $1000 \mathrm{rpm}$ for $5 \mathrm{~min}$ to separate the erythrocytes. $2 \%$ erythrocyte suspension was prepared by adding $49 \mathrm{~mL}$ phosphate buffer (pH 7.4) to $1 \mathrm{~mL}$ packed erythrocytes. Serial dilution of plant extracts were prepared using phosphate buffer. $1 \mathrm{ml}$ of citrated blood was mixed with equal volume of diluted plant extracts and the volume was adjusted to $5 \mathrm{~mL}$ by phosphate buffer. The mixture was allowed to stand for 20 minutes at room temperature and $\mathrm{O}$. D. was measured spectrophotometrically at $540 \mathrm{~nm}$ $[7,23]$.

\section{Results and discussion \\ Phytochemical screening:}

The results of phytochemical analysis of the leaf samples of $C$. tamala and $A$. marmelos are presented in Figure - 1. The result revealed that polyphenols is highest $(16.7 \pm 0.7 \mathrm{~g} / 100 \mathrm{~g}$ and $6.7 \pm 0.61 \mathrm{~g} / 100 \mathrm{~g}$ in C. tamala and A. marmelos respectively) and flavonoids occur in lowest quantity $(1.0 \pm$ $1.01 \mathrm{~g} / 100 \mathrm{~g}$ and $0.9 \pm 0.25 \mathrm{~g} / 100 \mathrm{~g}$ in $C$. tamala and $A$. marmelos respectively) among all the studied phytochemicals. Kumar et al. [16], reported 6.13 \pm 0.13 $\mathrm{g} / 100 \mathrm{~g}$ tannin, $2.09 \pm 0.17 \mathrm{~g} / 100 \mathrm{~g}$ saponin, $2.1 \pm 0.21 \mathrm{~g} / 100 \mathrm{~g}$ flavonoids, $0.13 \pm 0.1$ $\mathrm{g} / 100 \mathrm{~g}$ poly phenols in A. vasica. Dandapat et al. [10] also reported $1.38 \pm 0.5 \mathrm{~g} / 100 \mathrm{~g}$ tannin, $4.5 \pm 0.63 \mathrm{~g} / 100 \mathrm{~g}$ saponin, $0.65 \pm 0.2$ $\mathrm{g} / 100 \mathrm{~g}$ flavonoid, $1.73 \pm 0.4 \mathrm{~g} / 100 \mathrm{~g}$ polyphenol and $2.6 \pm 0.5 \mathrm{~g} / 100 \mathrm{~g}$ alkaloid in T. cordifolia. Phytochemical composition of A. marmelos and C. tamala have found in higher concentration than most of the studied plants. Tannin acts as an antibacterial substance by destabilization of cytoplasmic and plasma membranes, inhibition of extracellular microbial enzymes and metabolisms, and deprivation of the substrate required for microbial growth [25] or by inactivate microbial adhesions, 
enzymes, cell envelope transport proteins, and mineral uptake due to presence of hydroxyl (-OH) groups which posses toxicity to microorganisms [26]. The tannins also exert a direct protective effect against oxidative stress-induced cell death [27]. Saponins inhibit microbial growth by inhibiting DNA dependent RNA synthesis in saponine treated host [28] and are directly associated with antioxidant activities on serum lipids [29]. Flavonoids prevent cellular injury by direct scavenging of free radicals and inhibit carcinogenesis [30] and suppress bacterial growth by inhibiting action of several enzymes, chelate certain metal cations, affect protein phosphorylation [31]. Alkaloids posses anti-oxidizing effects, thus reduces the nitrate generation which is useful for protein synthesis, suppresses the transfer of sucrose from stomach to small intestine and also possess antibacterial activity [32]. Dandapat et al. [6] reported plant phenolics are potent inhibitors of a number of growth factor binding and signalling pathways implicated in cancer.

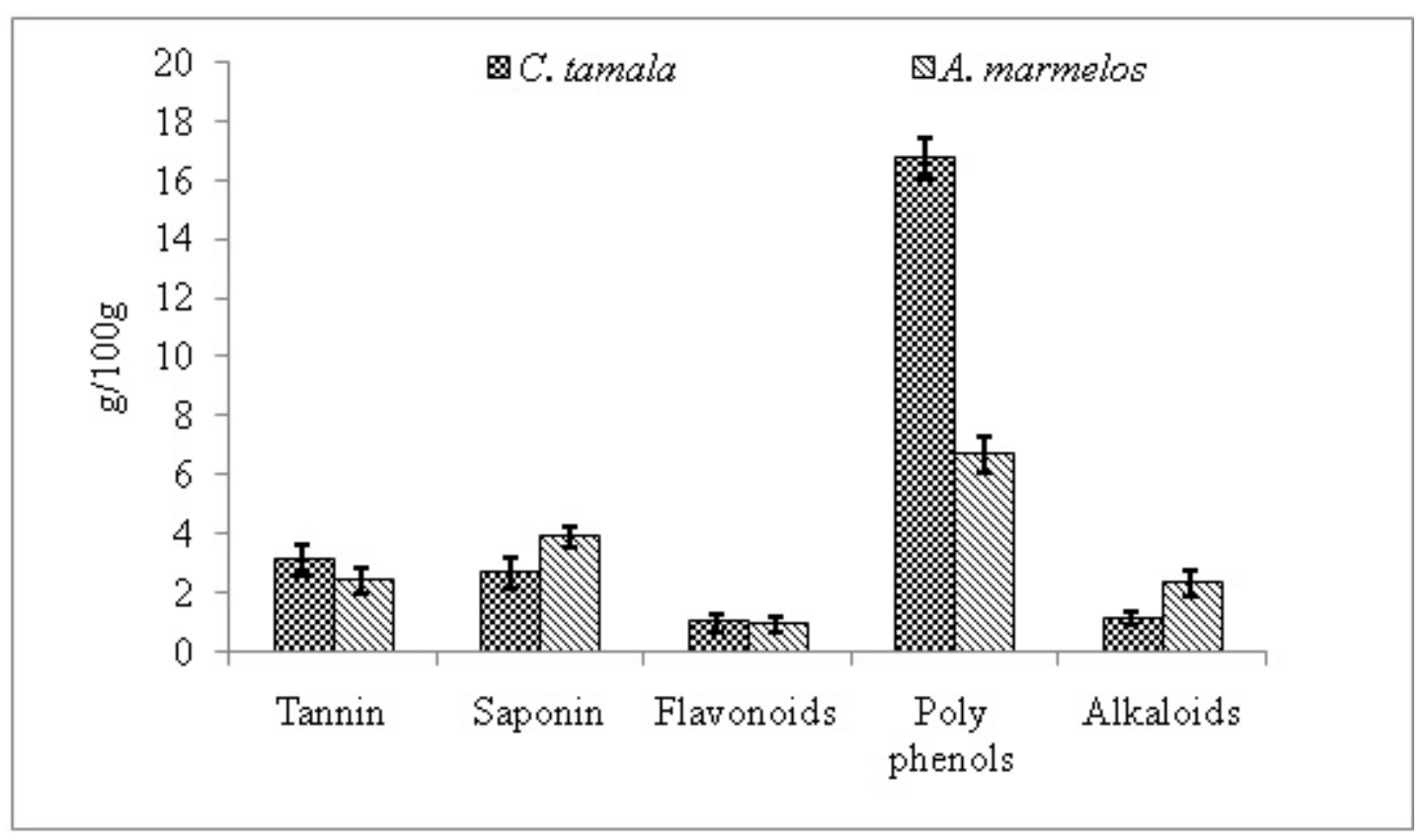

Figure 1: Phytochemicals from C. tamala and A. marmelos leaf in $\mathrm{g} / 100 \mathrm{~g}(\mathrm{M} \pm \mathrm{SD} ; \mathrm{n}=3)$

\section{Antibacterial assay:}

The anti pathogenic efficacy of methanolic extract of C. tamala and A. marmelos leaves were quantitatively assessed comparing with gentamycin on the basis of zone of inhibition (ZOI) and minimum inhibitory concentration (MIC) following agar diffusion method ( in Table-1and 2) and by broth dilution method (Fig-2 and 3). In the present investigation extract of the both plants were found to be effective against both the pathogens (Table-1) with compared standard antibiotic gentamycin (Table-2) in agar diffusion method. 
Table 1: ZOI and MIC of $C$. tamala and $A$. marmelos against $S$. aureous and $P$. mirabilis

\begin{tabular}{|c|c|c|c|c|}
\hline \multirow{2}{*}{ Concentration $(\mathrm{mg} / \mathrm{mL})$} & \multicolumn{4}{|c|}{ Zone of inhibition (in mm) } \\
\cline { 2 - 5 } & \multicolumn{3}{|c|}{ C. tamala } & \multicolumn{2}{c|}{ A. marmelos } \\
\cline { 2 - 5 } & S. aureus & P. mirabilis & S. aureus & P. mirabilis \\
\hline 0.18 & 0 & 0 & 0 & 0 \\
\hline 0.36 & 0 & 0 & 0 & 0 \\
\hline 0.612 & 0 & 0 & 0 & 0 \\
\hline 1.25 & 0 & 0 & 0 & 6 \\
\hline 2.5 & 6 & 0 & 4 & 9 \\
\hline 5 & 6 & 10 & 5 & 10 \\
\hline MIC $(\mathrm{mg} / \mathrm{mL})$ & 2.5 & 5 & 2.5 & 1.25 \\
\hline
\end{tabular}

Table 2: ZOI and MIC of Gentamycin against $S$. aureous and $P$. mirabilis.

\begin{tabular}{|c|c|c|}
\hline \multirow{2}{*}{ Concentration $(\mu \mathrm{g} / \mathrm{mL})$} & \multicolumn{2}{|c|}{ Zone of inhibition $(\mathrm{mm})$ against gentamycin } \\
\cline { 2 - 3 } & S. aureus & P. mirabilis \\
\hline 25 & 13 & 9 \\
\hline 50 & 18 & 13 \\
\hline 100 & 21 & 18 \\
\hline 200 & 25 & 21 \\
\hline 400 & 27 & 25 \\
\hline 800 & 34 & 27 \\
\hline MIC $(\mu \mathrm{g} / \mathrm{mL})$ & 25 & 25 \\
\hline
\end{tabular}

The broth dilution method showed more pronounced antimicrobial activity extract of the both plants through $100 \%$ inhibition of both the pathogens in the range of $1.25 \mathrm{mg}$ $5 \mathrm{mg} / \mathrm{mL}$ concentration.

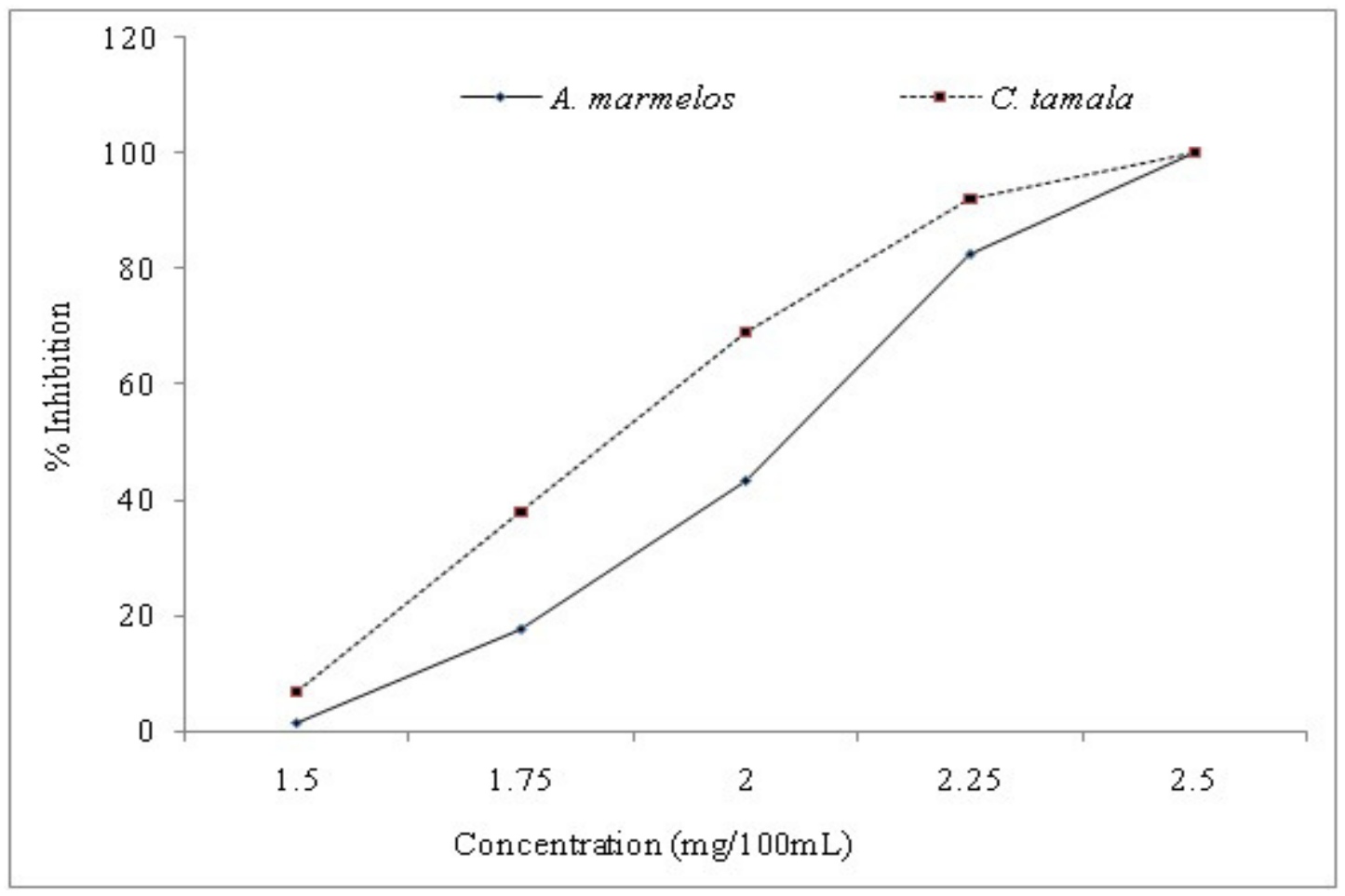

Figure 2: \% Inhibition of $S$. aureous in broth dilution method for methanolic leaf extract of C. tamala and A. marmelos. 


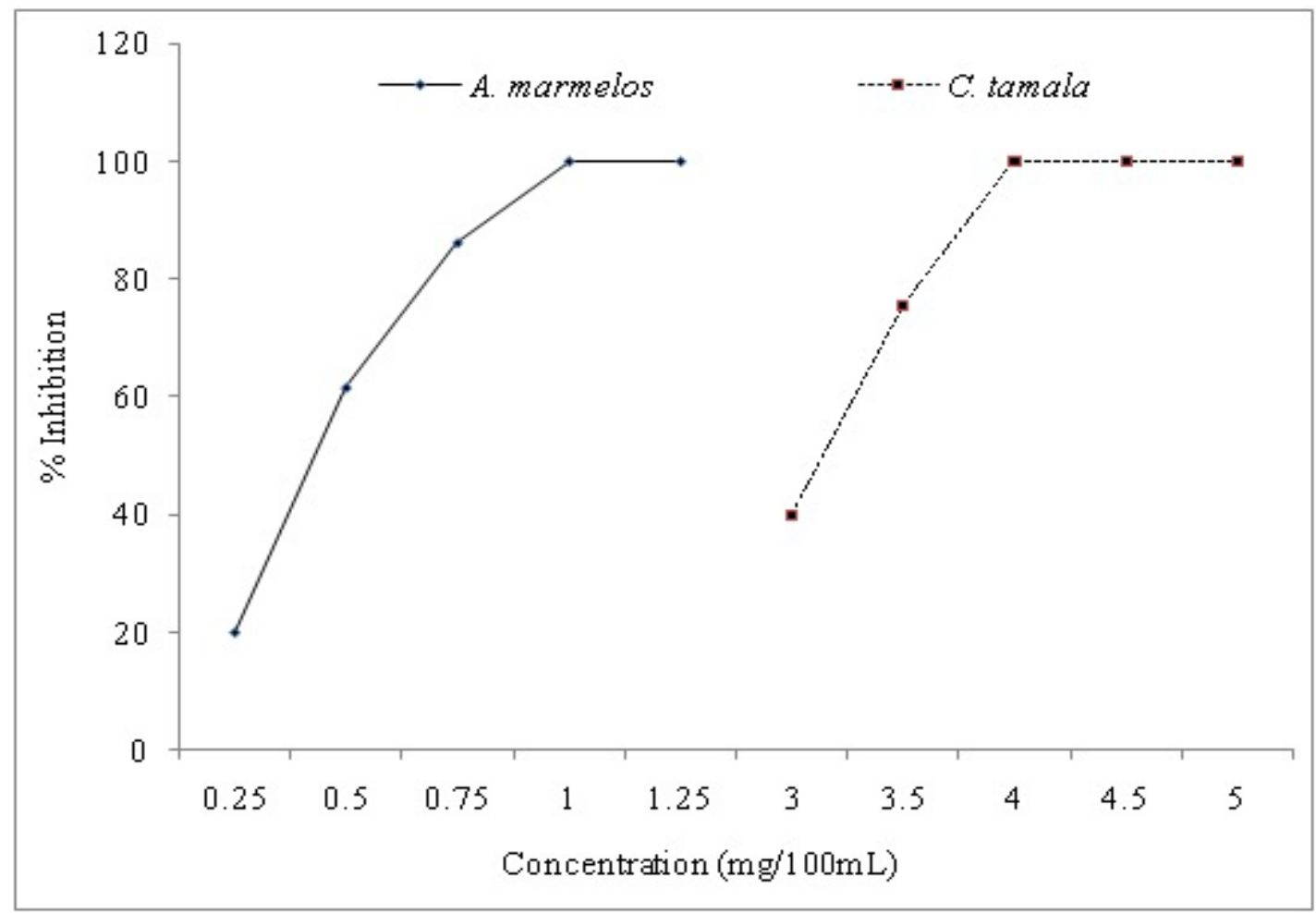

Figure 3: \% Inhibition of $\boldsymbol{P}$. Mirabilis in broth dilution method for methanolic leaf extract of $C$. tamala and $A$. marmelos.

Kumar et al. [7,4] worked out on metanolic extract of Calotropis procera and found $4 \mathrm{~mm}-10 \mathrm{~mm}$ ZOI in agar diffusion method. They also reported the plant extract showed $100 \%$ inhibition at $10 \mathrm{mg} / \mathrm{mL}$ and 5 $\mathrm{mg} / \mathrm{mL}$ concentration against $S$. aureous and $P$. miabilis respectively and also said that methanolic extract is more effective than other extracts because polar and non polar components of the plant material are effectively extracted through an oraganic solvent. C. tamala possess antibacterial activity due to the presence of different phenolic compound such as cinnamicaldehyde, eugenol and cinnamic acid etc. An important characteristic of these components is hydrophobicity, which enable them to partition the lipids of the bacterial cell membrane and mitochondria, disrupt the cell structure and rendering the more permeable [33]. Extensive leakages from bacterial cells or exits of critical molecules and ions will lead to death [34]. The antibacterial activity $A$. marmelos leaf extract is due to presence of active phenolic compound eugenol and cuminaldehyde they inhibit protein synthesis either at transcription or at trainslation level and also inhibit synthesis of peptido-glycan [35].

\section{Anioxidant assay:}

Result of total antioxidant activity of aqueous extract of both the plants expressed as the $\mathrm{mg} / \mathrm{mL}$ of ascorbic acid $/ 100 \mathrm{mg}$ presented in figure-3. C. tamala showed higher antioxidant activity (7\%) equivalent to ascorbic at $100 \mu \mathrm{L}$ of leaf extact. 


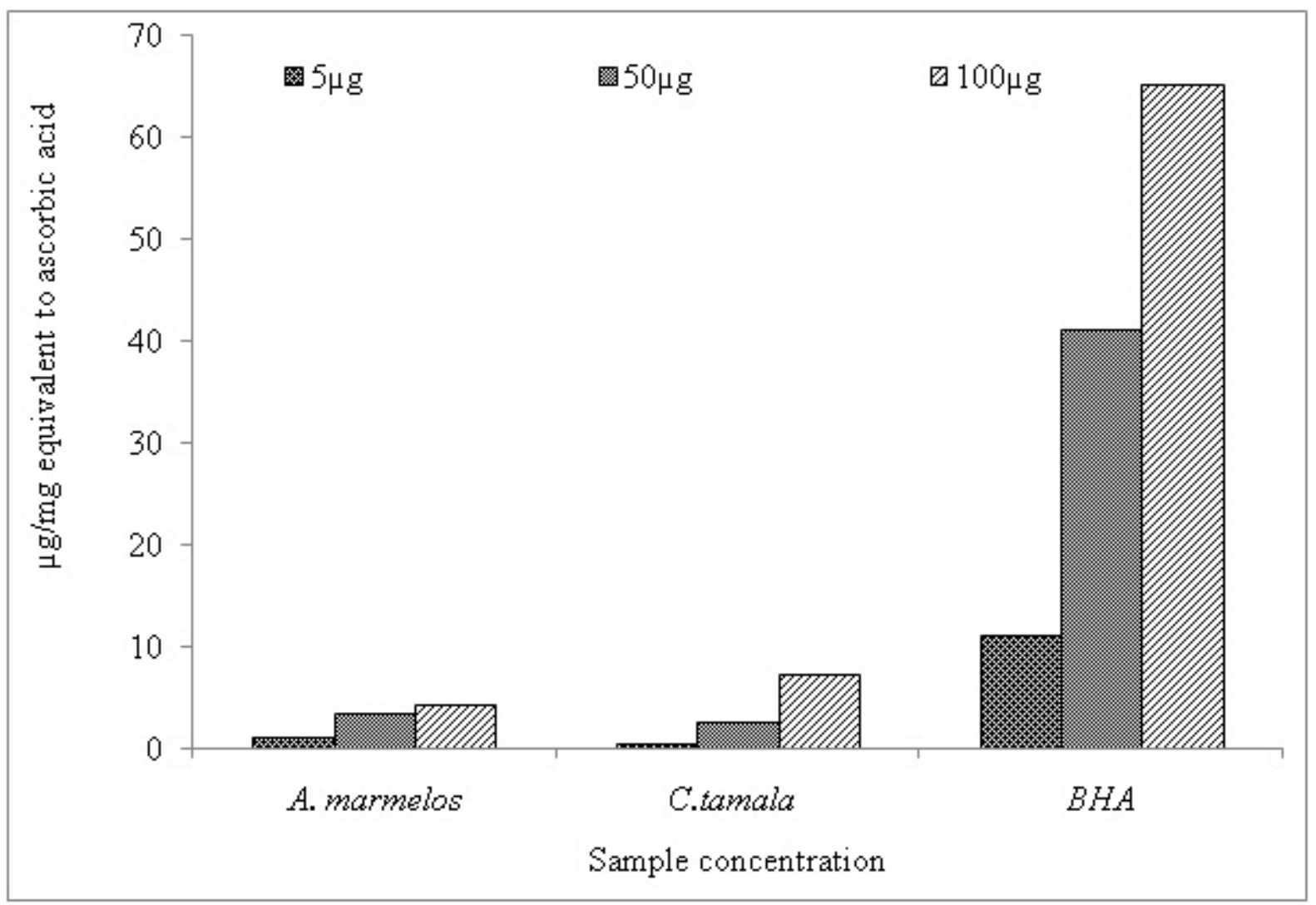

Figure 4: Total antioxidant activity of $A$. marmrlos and $C$. tamala leaf extract in comparison with Butylated hydroxyl anisole (BHA).

Kumar et al. [5] reported $0.1 \%, 4 \%, 8 \%$ and and $0.2 \%, 0.8 \%, 2.3 \%$ total antioxidant activity of $V$. negundo and $A$. vasica respectively. Kumar et al. [17] reported total antioxidant activity of $C$. procera is $0.1 \%, 0.2 \%$ and $0.3 \%$. C. tamala and $A$. marmelos possess high antioxidant activity among the studied plants. A. marmelos contains bioactive compounds like eugenol and marmesinin are independently showed their activity in oxidative stress by free radical scavenging [36]. $C$. tamala also posses eugenol and another bioactive chemical linalool have free radical scavenging capacity due to presence of electron repelling group in o- position [37].

\section{Cytotoxicity:}

Result of haemolytic activity of $C$. tamala and A. marmelos presented in fig-5 and 6. Leaf extract of both the plant did not show haemolysis at $0.2 \mathrm{mg} / \mathrm{mL}-1 \mathrm{mg} / \mathrm{mL}$. Kumar et al. [23] reported $0.2 \mathrm{mg} / \mathrm{mL}$ $0.4 \mathrm{mg} / \mathrm{mL}$ leaf extract of $C$. procera is safe but more concentrated leaf extract increase in the hemolytic activity with time of incubation. Since $C$. tamala and A. marmelo did not show haemolysis, hence the plant extract is non cytotoxic. 


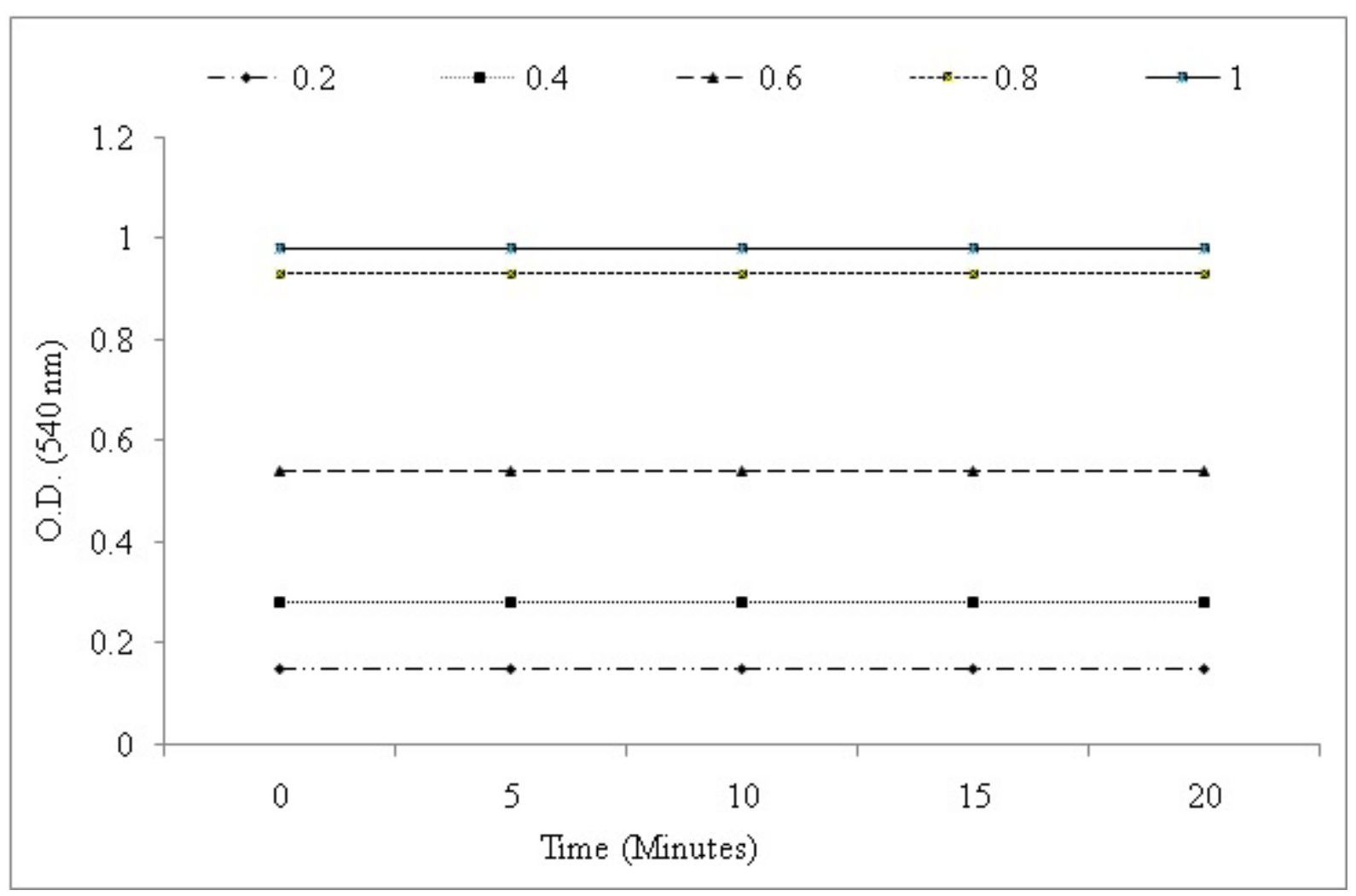

Figure 5: Cytoxicity of $A$. marmelos leaf extract by Haemolytic method.

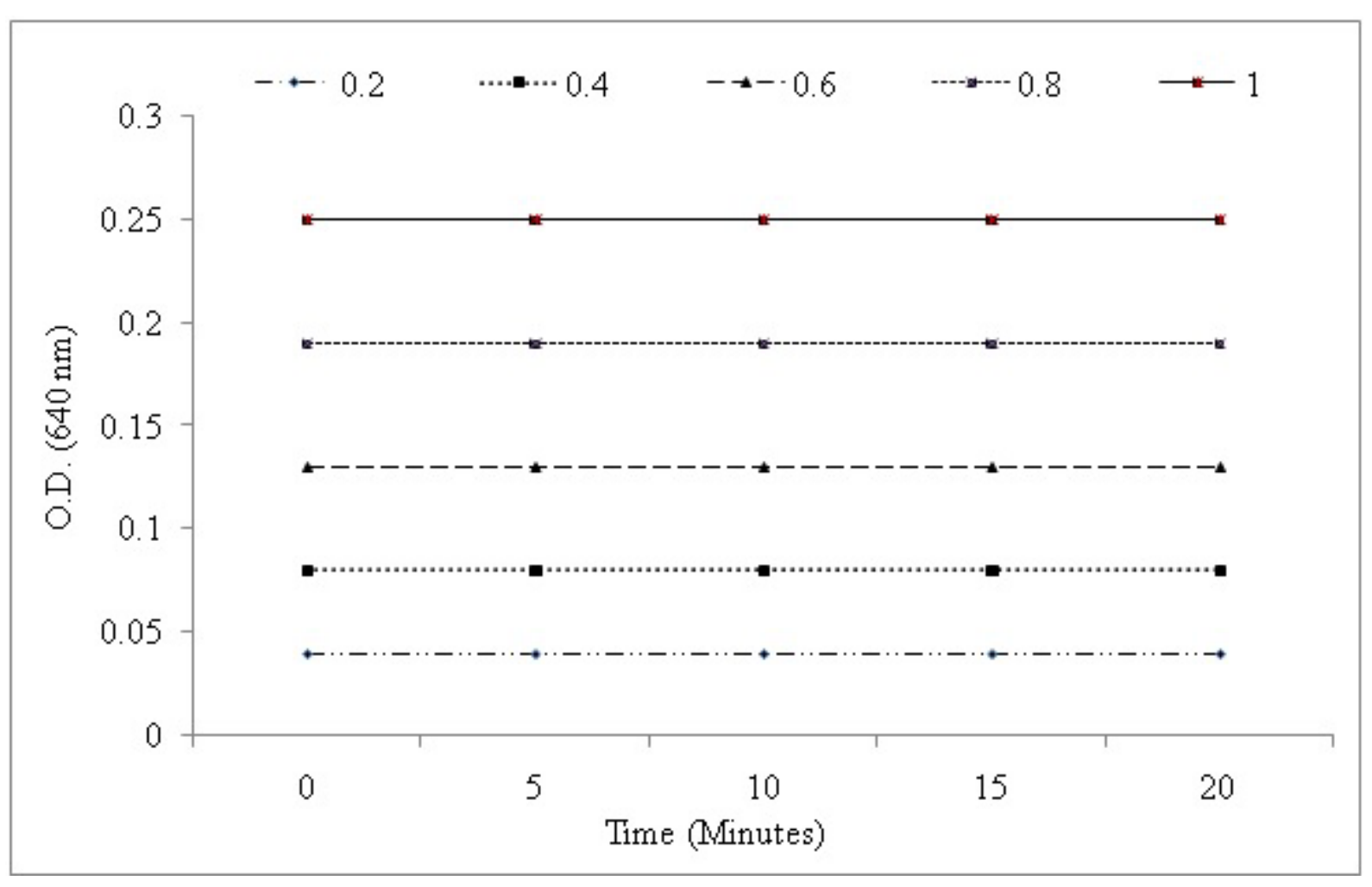

Figure 6: Cytoxicity of $C$. tamala leaf extract by Haemolytic method. 


\section{Conclusion:}

Inspite of presence of phytochemicals in C. tamala and A. marmelos, possess high antioxidant and anti-pathogenic activity, the leaf extracts of above plants is safe at higher concentration, thus it can be used as medicinal supplement.

\section{Acknowledgement:}

The authors acknowledged the facilities provided by the Department of Zoology, Ranchi University, Ranchi, Jharkhand, India.

\section{References:}

1. Solanki R., 2010, Some medicinal plants with antibacterial activity, Int. J. Comprehens. Pharm. 4(10): 1-4.

2. Dandapat S., Kumar M., Kumar A., Sinha. M.P., 2013, Antipathogenic efficacy of methanolic leaf extract of Cinnamomum tamala (Buch.-Ham.) and Aegle marmelos (L.) with their nutritional potentiality, The Bioscan; Supplement on Medicinal Plants, 8(2): 635-641.

3. Cheng J., Dai F., Zhou B., Yang L., Liu Z., 2007, Antioxidant activity of hydroxycinnamic acid derivatives in human low density lipoprotein: mechanism and structure activity relationship, Food Chemistry, 104: 132-139.

4. Aruoma I.O., 1998, Free radicals, oxidative stress and antioxidant in human health and disease, JAOCS, 75(2): 199-212.

5. Kumar M., Kumar A., Dandapat S., Sinha M.P. 2013. Phytochemical Screening and Antioxidant potency of Adhatodavasicaand Vitex negundo, The Bioscan; Supplement on medicinal plants, 8 (2): 727-730.

6. Dandapat S., Kumar M., Kumar A., Sinha. M.P., 2013, Therapeutic efficacy and nutritional potentiality of Cinamomum tamala, Int. J.Pharm., 3(4): 779-785.

7. WHO., 1998, Quality control method for medicinal plant materials. Library cataloguing in publication data, $\mathrm{p}$, 44.

8. Chopra R.N., Nayar S.L. Chopra I.C., 1956, Glossary of Indian Medicinal Plant, fifth Edition, IBH publication (P) Ltd, New Delhi, pp, 8-14.

9. Kirtikar K.R., Basu B.D., 1995, Indian medical plant, second Edition, International book publication, Mumbai, India, pp, 499-502.

10. Dandapat S., Kumar M., Kumar A., Sinha. M.P., 2013, Phytochemical screeningand nutritional potentiality of Adhatoda vassica (Nees.) Cinnamomum tamala (Buch.Hem.) Aegle marmelos (L.) and Tinospora cordifolia (Thunb.) leaves for therapeutic efficacy, Columban Journal of Life Sciences, In press.

11. Kumar M., Dandapat S., Kumar A., Sinha M.P., 2013, Determination of nutritive value and mineral Elements of Five- Leaf Chaste Tree (Vitex negundo) And Malabar Nut (Adhatoda vasica Nees), Acad. J. Plant Sci., 6(3): 103-1082

12. Ramamoorthy P.K., Bono, A., 2007, Antioxidant activity, total phenolic and flavonoids content of Morinda citrifolia fruit extacts from various extraction processes, J. Engg. Sci. Tech, 2(1): 70-80.

13. Lin J.Y., Tang C.Y., 2007, Determination of total phenolic and flavonoids contents in selected fruits and vegetables, as well as their stimulatory effects on mouse spleenocyte proliferation, Food Chem, 101(1): 140-147.

14. Helrich K., 1990, Official Methods of Analysis of the Association of Official Analytical Chemists. AOAC, Inc. (15th ed).Virginia, USA, pp, 425-497.

15. Obadona B.O., Ocheko P.O., 2001, Phytochamical studies and comparative efficacy of the crude extract of some homeostatic plants in Edo and Delta states of Nigeria, 
Glob. J. Pure and Appl. Sci., 86: 2003-2008.

16. Kumar M., Kumar A., Dandapat S., Sinha M.P., 2013, Anti-typhoid activity of Adhatoda vasica and Vitex negundo, Persian Gulf crop protection, 2(3): 64-75.

17. Kumar A., Dandapat S., Kumar M., Sinha M.P., 2013, Phytochemical properties and antioxidant activity of Calotropis procera (Ait.) R. Br. The Ecoscan; Special issue, 4(8): 195200.

18. Threlfall E.J., Fisher I.S.T., Ward L., Tschape H., Gernersmidt P., 1999, Harmonization of antibacterial susceptibility testing for Salmonella: Result of a study by 18 national reference laboratories within the Europian Union-funded Enter-Net group, Microbiol. Drug Resist, 5: 195-199.

19. Walker R.D., 2000, Antimicrobial susceptibility testing and interpretation of results. In: Prescott, I.F., Baggot, I.D., Walker, R. D., Ames, I. A. (3rd Ed). Antimicrobial Therapy in Veterinary Medicine. Iowa State University Press, pp, 1226.

20. Kumar M., Kumar A., Dandapat S., Sinha M.P., 2013, Growth inhibitory impact of $A$. vasica and $V$. negundo on some human pathogen. The Ecoscan; Special issue, 4: 241-245.

21. Prieto P., Pineda M., Aguilar, M., 1999, Spectrophotometric quantitation of antioxidant capacity through the formation of phosphomolybedate complex: specific application to the determination of vitamin $\mathrm{E}$, Analytical Biochem, 269: 337-341.

22. Kumar A., Dandapat S., Kumar M., Sinha M.P., 2013, Antioxidant activity and Pharmacological screening of Tinospora cordifolia, The Bioscan 8(2): Supplement on Medicinal Plants, 689-693.
23. Kumar A., Dandapat S., Kumar M., Sinha M.P., 2013, Antipathogenic efficacy and haemolytic activity of Calotropis procera leaves, World Journal of Zoology, 8(4): 366-370.

24. Puupponen-Pimia R., Nohynek L., Alakomi H.L., Oksman-Caldentey K.M., 2004, Bioactive berry compounds- novel tools against human pathogens, Appl. Microbiol. Biotechnol., 67: 8-18.

25. Min B.R., Barry T.N., Attwood G.T., Mc Nabb W.C., 2003, The effect of condensed tannins on the nutrition and health of ruminants fed fresh temperate forages: a review, Anim. Feed Sci. Technol, 106: 3-19.

26. Spencer J.P., Schroeter H., Rechner A.R., Rice-Evans C., 2001, Bioavailability of flavan-3-ols and procyanidins: gastrointestinal tract influences and their relevance to bioactive forms in vivo, Antioxid Redox Signal, 3(6): 1023-1039.

27. Khan M.A., Naqvi T.S., Naqvi M.S., 2012, Identification of phytosaponin as novel biodynamic agents, Asian. $J$. Exp. Biol. Sci., 3(3): 495- 467.

28. Rodrigues H.G., Diniz Y.S., Faine L.A., Galhardi C.M., Burneiko R.C., Almeida J.A., Ribas B.O., Novelli E.L, 2005, Antioxidant effect of saponin: potential action of a soybean flavonoid on glucose tolerance and risk factors for atherosclerosis, Int J. Food Sci. Nutr., 56(2): 79-85.

29. Stefani E.D., Boffetta P., DeneoPellegrini H., 1999, Dietary antioxidantsand lung cancer risk: a case-control study in Uruguay,. Nutr. Cancer., 34: 100-110.

30. Middleton E.J., 1998. Effect of plant flavonoids on immune and inflammatory cell function, $A d v$. Exp. Med. Biol, 439: 175-182.

31. Isaac O.O., Chinwe J.A. 2001, The phytochemical analysis and antibacterial screening of extract of 
Tetrecarpidum conophorum, J. Chem. Soc. Nig, 26(1): 53-55.

32. Sikkema J., Bont de J.A.M., Poolman B., 1994, Interactions of cyclic hydrocarbons with biological membranes, J. Biol. Chem, 26(9): 1022-8028.

33. Denyer S.P., Hugo W.B., 1991, Biocide-included damage to the bacterial cell membrane. The society for applied bacteriology (pp. 171188). Technical series No.-27. Oxford Blackwell scientific publication, Oxford.

34. Rajan S., Jeevagangai T.J., 2009, Studies on the antibacterial activity of Aeglemarmelos-fruit pulp and its preliminary phytochemistry, J. Bas. Appl. Biol., 3(1\&2): 76-81.

35. Vimal V., Devaki T., 2004, Linear furanocouramin protects rat myocardium against lipid peroxidation and memebrane damage duringexperimental myocardium injury, Biomed Pharmacother, 58: 393-400.

36. Celik S., Ozkaya A., 2002, Effect of intraperitoneally administered lipoic and fatty acid, vitamin E, and lnalool on the level of total lipid and fatty acids in gunea pig brain with oxidative stress induced by $\mathrm{H}_{2} \mathrm{O}_{2}, J$ Biochem Mol Biol, 35: 547-552. 